\title{
Lypsylehmien kestävyyttä kuvaavat tunnusluvut
}

\author{
Jouni Nousiainen, Hannele Khalili ja Pekka Huhtanen \\ MTT, Eläinravitsemus, 31600 Jokioinen \\ Jouni.Nousiainen@mtt.fi, Hannele.Khalili@mtt.fi,.Pekka.Huhtanen@mtt.fi
}

\section{Johdanto}

Lypsylehmien käyttöikä, poistettujen lehmien elinikänä mitattuna, on Suomessa laskenut 30 vuoden aikana 1.9 vuotta ja on nyt pysähtynyt 4.9 vuoteen (Kuva 1). Trendissä näkyvät nopeampana alenemisena maidontuotannon rajoittamistoimenpiteet 1960- ja 1970- lukujen vaihteessa ja soluluvun käyttöönotto maidon hinnoittelussa 1990- luvun alussa. Lehmien käyttöiällä on yhteyksiä erittäin moniin nautakarjatalouden osa-alueisiin. Maidontuotannon tehokkuuteen ja taloudellisuuteen vaikuttavat hiehojen kasvatuskustannusten osuus maidontuotannon kustannuksista ja lehmien parhaiden tuotantovuosien, 4-6 lypsykausien jääminen saavuttamatta suurella osalla lehmistä. Lisääntynyt vähentää myös maidontuotannon typpi- ja fosforipäästöjä (Voutilainen ym. 2003). Kun nykyisin lähes kaikki lehmävasikat joudutaan käyttämään uudistukseen, tämä rajoittaa selvästi lehmävalintaa ja siten karjan geneettistä edistymistä. Edelliseen tilanteeseen liittyy alentunut mahdollisuus liharotujen käyttöön sekä uudistusvasikoiden suuren tarpeen että korkean hiehopoikimisten osuuden takia. Lisääntynyt käyttöikä nostaisi myös nuoren naudan osuutta naudanlihantuotannosta lehmänlihaan verrattuna. Ja unohtaa ei sovi tuotannon eettisyyttä, sillä kun nykyinen poistoikä on huomattavasti alempi kuin lehmien potentiaalinen elinikä, voi maidontuotannon imagoa pitää osittain kyseenalaisena. Yleiskatsaukset lypsylehmien kestävyydestä ovat esittäneet mm. Dredge (2003) ja Radke ja Shook (2001).

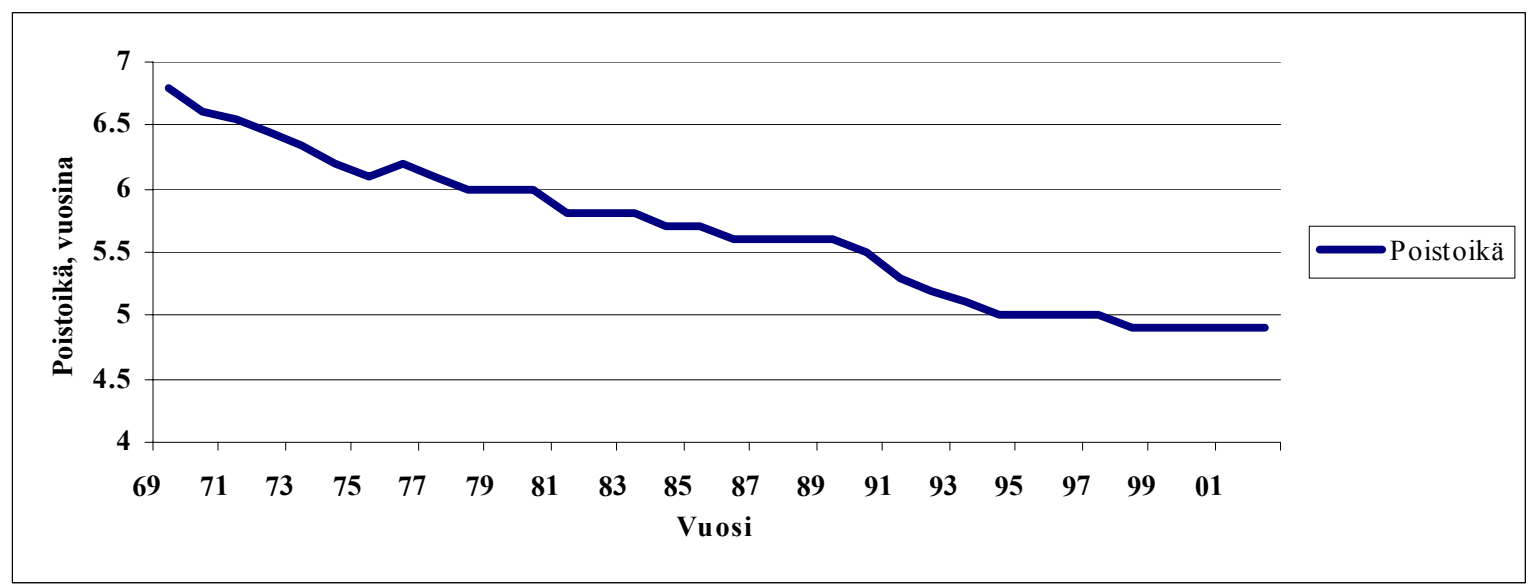

Kuva 1. Tarkkailulehmien keskimääräinen poistoikä vuosina 1969-2002.

\section{Aineisto ja menetelmät}

Tässä esityksessä on tarkoitus esitellä erilaisia lypsylehmien kestävyyteen liittyviä tunnuslukuja, niiden merkitystä ja hyödyntämistapoja. Lähdetietona käytetään kirjallisuutta, esimerkkisimulointeja ja Pohjois-Savon karjantarkkailutietoja vuosilta 1996-2000. Karjantarkkailuaineistossa on mukana 1786:n tarkkailutilan 48699:n poistetun lehmän elinikäistuotos-, ikä- ja poikimatietoja. Karjakohtaisina tietoina mukana on uudistuksen osuus, keskituotos ja karjan keskilehmäluku. Ne lehmät, joiden syntymäaikaa ei ole ollut tiedossa, on poistettu aineistosta. Koko lehmäjoukosta on laskettu tavanomaisimmat kestävyystunnusluvut ja samojen tunnuslukujen karjakohtaisten mediaanien väliset korrelaatiot. Mediaani valittiin käytettäväksi keskiarvon sijasta, koska se antaa paremman kuvan aineistosta, joka ei ole normaalisti jakautunut. Lehmäkohtaisten kestävyystunnuslukujen konkretisoimiseksi simuloitiin kuusi kertaa poikivan, korkeatuottoisen esimerkkilehmän koko eliniän aikaiset tuotokset ja rehunkulutus ruokintanormeja käyttäen. Koonti poistettujen lehmien tiedoista lasketuista tunnusluvuista on esitetty taulukossa 1 ja karjakohtaisten mediaanien tietoja taulukossa 2. 
Taulukko 1. Poistettujen lehmien ( $\mathrm{N}=48699)$ kestävyyden tunnuslukuja

\begin{tabular}{lccccccc}
\hline Tunnusluku & Keskiarvo & Keskihajonta & P10 & P25 & P50 & P75 & P90 \\
\hline Ikä, vuosia & 4.97 & 1.971 & 2.64 & 3.47 & 4.67 & 6.12 & 7.66 \\
Tuotantoikä (herdlife), vuosia & 2.82 & 1.971 & 0.49 & 1.31 & 2.52 & 3.98 & 5.51 \\
Lypsykausi390 & 2.64 & 1.871 & 0.45 & 1.17 & 2.37 & 3.76 & 5.14 \\
Poikimakerta & 3.12 & 1.851 & 1 & 2 & 3 & 4 & 6 \\
Elinikäinen maitotuotos, kg & 20420 & 15179.3 & 3306 & 8733 & 17580 & 28945 & 41197 \\
Elinikäinen maitotuotos /ikä päivinä & 9.8 & 4.56 & 3.4 & 6.8 & 10.2 & 13.0 & 15.4 \\
\hline
\end{tabular}

P10, P25, P50, jne. ovat persentiilejä, jotka kuvaavat, kuinka monta \% havainnoista on alle kyseisen luvun, $\mathrm{P} 50=$ mediaani.

\section{Lehmän ikään ja poikimisiin liittyvät tunnusluvut}

Lehmän ikää ja poikimisten määrää on kuvattu useilla eri tunnusluvuilla, jotka eivät yksinään kerro juuri mitään, mutta koska ne on helppo laskea ja korrelaatiot monimutkaisempiin, maidontuotannon taloutta, tehokkuutta ja määrää kuvaaviin muuttujiin ovat vahvoja (Taulukko 3), ovat ne hyvin käyttökelpoisia.

Taulukko 2. Karjojen ( $\mathrm{N}=1786)$ kestävyystunnuslukujen mediaanien jakautuminen, lehmätiedot poistetuista

\begin{tabular}{lccccccc}
\hline Tunnusluku & Keskiarvo & Keskihajonta & P10 & P25 & P50 & P75 & P90 \\
\hline Ikä, vuosia & 4.86 & 0.766 & 3.99 & 4.33 & 4.78 & 5.27 & 5.83 \\
Tuotantoikä (herdlife), vuosia & 2.71 & 0.754 & 1.89 & 2.17 & 2.61 & 3.10 & 3.68 \\
Lypsykausi390, LK390 & 2.53 & 0.702 & 1.75 & 2.00 & 2.46 & 2.91 & 3.46 \\
Poikimakerta & 2.97 & 0.747 & 2 & 2.5 & 3 & 3 & 4 \\
Elinikäinen maitotuotos, kg & 18847 & 5500.6 & 12564 & 15003 & 18129 & 21865 & 25988 \\
Elinikäinen maitotuotos /ikä päivinä & 10.4 & 1.83 & 8.2 & 9.2 & 10.3 & 11.6 & 12.6 \\
Keskituotos, kg maitoa/vuosi & 7468 & 1017.9 & 6203 & 6837 & 7481 & 8146 & 8701 \\
Uudistusprosentti, \% & 33.2 & 7.61 & 23.7 & 28.0 & 32.8 & 37.8 & 43.0 \\
\hline
\end{tabular}

P10, P25, P50, jne. ovat persentiilejä, jotka kuvaavat, kuinka monta \% havainnoista on alle kyseisen luvun, $\mathrm{P} 50=$ mediaani.

Lehmän ikä on kaikkein yksinkertaisin laskettava muuttuja, poistopäivämäärä vähennettynä syntymäpäivämäärästä.. Ikä on ennen kaikkea välttämätön muuttuja, kun simulaatioissa mallinnetaan lehmän kasvatukseen ja ylläpitoon sen elinaikana kulunutta rehumäärää.

Lehmän käyttöikä ilmoitetaan Suomessa kestävyysindeksiä laskettaessa ja useissa muissa maissa aikana ensimmäisestä poikimisesta poistoon. Tälle herdlife- termille ei ole olemassa yksiselitteistä suomenkielistä nimitystä, käyttöikätermi ei ole täysin vakiintunut. Herdlife on tärkeä muuttuja mallinnettaessa lypsylehmän optimaalista poistoikää, mutta sen heikkona puolena on, että herdlife ei ota huomioon lehmän ikää sen poikiessa ensimmäistä kertaa eikä poikimavälien pituutta.

Taulukko 3. Karjakohtaisten muuttujien mediaanien keskinäisiä korrelaatioita.

\begin{tabular}{lcccccc}
\hline & Ikä & Tikä & Pker & Emaito & Pvmaito & Uud. \\
\hline Tuotantoikä (herdlife), tikä & 0.97 & & & & & \\
Poikimakerta, pker & 0.86 & 0.88 & & & & \\
Elinikäinen maitotuotos, emaito & 0.81 & 0.84 & 0.77 & & & \\
Elmai/ikä päivinä, pvmaito & 0.44 & 0.49 & 0.48 & 0.85 & & \\
Uudistusprosentti, uud. & -0.67 & -0.68 & -0.61 & -0.60 & -0.40 & \\
Keskituotos & -0.22 & -0.19 & -0.11 & 0.28 & 0.65 & 0.06 \\
\hline
\end{tabular}

Kaikki korrelaatiot ovat tilastollisesti merkitseviä.

Lehmän poikimakertojen määrä on nykytilanteessa hieman järeä ja porrasmainen muuttuja, koska yksi reilun vuoden poikimakerta on noin 30\% lehmän koko tuotantoiästä Tarkempana muuttujana olisi käyttökelpoinen lehmän lypsykausien määrä, jonka voisi laskea kaavalla: (Poikimakerta1)+(aikaa poikimisesta / x). Ongelmana on käyttäisikö x:n arvona 305:a tai 390:a vai vieläkö suurempaa lukua eli milloin lypsykausi on "täysi". Jos aikaa poikimisesta menee yli x:n arvon, se on laskennassa pysäytettävä x:n arvoon, jotta tulos ei ylitä ykköstä. Lypsykausimuuttujan voisi esimerkiksi il- 
maista tunnuksella LK305, LK390, LK547, riippuen mitä lukua on käytetty x:n arvona. Jos lehmä poikisi 365 päivän välein, niin LK365 ja käyttöikä (herdlife) vuosina esitettynä olisivat yhtä suuria.

Tarkin tapa lypsylehmän elinkaaren kuvaamiseen on seurata, kuinka suuri osa tietystä alkuperäisestä, ensimmäisen kerran poikineesta lehmäjoukosta, poikii keskimäärin toisen, kolmannen, neljännen jne. kerran (survival rate). Lisäksi voi laskea poikimavälejä, ja keskimääräisen ajan, milloin lehmät on poistettu eri poikimisten välillä ja mahdollisesti tuotostietojakin (Dürr ym. 1997). Vertailua Pohjois-Savossa vuonna 1996 ja Quebecissä Kanadassa 1988 (Dürr ym. 1997) ensimmäistä kertaa poikineiden lehmien välillä on esitetty taulukossa 4 .

Taulukko 4. Lehmien elinkaari neljänteen poikimiseen asti.

\begin{tabular}{lcc|}
\hline \multicolumn{1}{|c}{ Alue ja 1. poikimavuosi } & Kanada Quebec 1988 & Suomi Pohjois-Savo 1996 \\
\hline 2. poikiminen, \% ensikoista & 71 & 79 \\
1. poikimaväli, päiviä & 395 & 389 \\
1. poistoajankohta, päiviä 1. poikimisesta & 213 & 216 \\
3. poikiminen, \% ensikoista & 51 & 57 \\
2. poikimaväli, päiviä & 397 & 383 \\
2. poistoajankohta, päiviä 2. poikimisesta & 232 & 227 \\
4. poikiminen, \% ensikoista & 34 & 37 \\
3. poikimaväli, päiviä & 397 & 385 \\
3. poistoajankohta, päiviä 3. poikimisesta & 236 & 216 \\
\hline
\end{tabular}

\section{Lehmän tuotantoon ja tuotannon tehokkuuteen liittyvät tunnusluvut}

Elinikäistuotos lasketaan lehmän maito-, rasva- ja valkuaistuotoksen summana ensimmäisestä poikimisesta lähtien. Jakauma on hieman suuriin lukuihin päin vino, koska keskiarvo on mediaania suurempi (Taulukko 1). Tutkimusaineistossa oli 50-tonnareita $4.67 \%$ ja yli $100000 \mathrm{~kg}$ maitoa tuottaneita lehmiä 19 kappaletta (0.04 \%). Karjojen välinen vaihtelukerroin (100 x keskihajonta/keskiarvo) on selvästi suurempi elinikäistuotoksissa $(29.2 \%)$ kuin keskituotoksissa (13.6 \%).

Helposti laskettava muuttuja, jolla voi kuvata lehmän biologista ja taloudellista tehokkuutta, on jakaa elinikäistuotos lehmän iällä päivinä. Tämä tunnusluku ottaa huomioon tuotostason, eläimen iän ensimmäistä kertaa poikiessa, ummessaoloajat ja poikimavälit. Mikään muu yhtä vaivattomasti laskettavissa oleva muuttuja ei ole yhtä monipuolinen. Poistetusta lehmistä noin $50 \%$ oli saavuttanut arvon 10 , noin $10 \%$ tason $15 \mathrm{~kg} / \mathrm{pv}$ ja $20 \mathrm{~kg} /$ päivä vain $0.72 \%$ (350 lehmää)

Kun lehmän elinikänään kuluttaman rehun energiamäärän jakaa elinikäistuotoksella, saadaan hyvin elinikäistä rehun hyväksikäyttöä kuvaava tunnusluku. Kuvasta 2 näkyy hyvin suuri potentiaali, joka käyttöiän parantamisella olisi rehuhyötysuhteeseen.

Yksinkertaisin käyttöiän taloudellisuutta kuvaava tunnusluku saadaan vähentämällä elinikäisen maitotuotoksen arvosta elinikäisen rehunkulutuksen arvo. Kuvassa 2 oleva (MT-RK)/IKÄ- käyrä on laskettu käyttämällä maidon arvona $0.35 €$ ja rehuyksikön $0.16 €$ ja jakamalla erotus lehmän iällä päivinä. Tarkka käyttöiän talousvaikutusten arviointi on huomattavasti monimutkaisempaa, huomioon on otettava mm. uudistuseläimen ja poistettavan eläimen hintaero, rehujen ja tuotteiden hintojen kausivaihtelu, eläimen tuotospotentiaali ja sairastumisriski eri poikimakertoina (esim. Rajala-Schultz ym. 2000).

\section{Karjaa kuvaavat tunnusluvut}

Karjan tietyssä ajassa tapahtuvaa uudistuksen osuutta kutsutaan englannin kielellä nimityksellä culling rate. Suomalaisena nimityksenä on käytetty poistoprosenttia (Dredge 2003). Tämä tunnusluku lasketaan jakamalla tiettynä aikana (vuosi) karjasta poistettujen lehmien määrä karjan keskilehmäluvulla. Sattuman vaikutuksen eliminoimiseksi ja yleensäkin Suomen pienien karjojen takia luku kannattaa laskea pidemmältä aikaväliltä, kuten tässä tutkimuksessa käytetyltä viideltä peräkkäiseltä vuodelta. Poistoprosentin suurimmat vahvuudet ovat sen helppo laskeminen ja ymmärrettävyys, heikkoutena suuri herkkyys karjakoon muutoksille. Teoreettisessa ideaalitilanteessa (vakiokarjakoko, kaikki lehmäpaikat jatkuvasti täynnä, ei jo poikineiden lehmien ostoja) poistoprosentti on laskettavissa jakamalla luku 100 käyttöiällä (herdlife) vuosina. Edellä mainituista syistä aineiston uudistusprosentti oli matalampi kuin keskimääräisen herdlife-käyttöiän perusteella olisi voinut olettaa (Taulukko 2). 


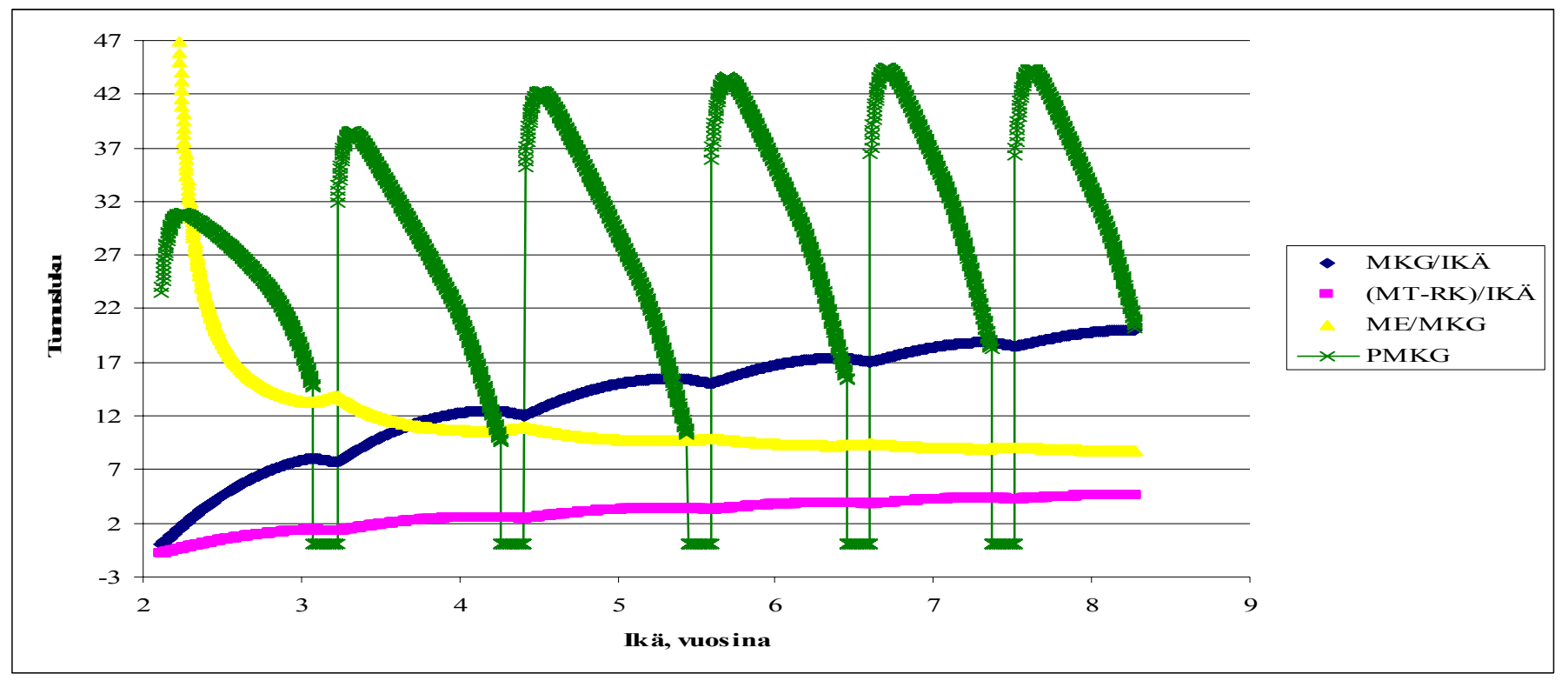

Kuva 2. Korkeatuottoisen lehmän tuotannon elinikäistä tehokkuutta ja kannattavuutta kuvaavia muuttujia. MKG/IKÄ= elinikäinen maitotuotos kg/ikä päivinä; (MT-RK)/IKÄ =maitotuottorehukustannus, €/ikä päivinä; $\mathrm{ME} / \mathrm{MKG}=$ elinikäinen rehunkulutus, $\mathrm{MJ}$ muuntokelpoista energiaa/elinikäinen maitotuotos, $\mathrm{PMKG}=$ päivittäinen maitotuotos, $\mathrm{kg}$.

Karjan keskipoikimakerta lasketaan Suomessa keskiarvona vuoden viimeisenä päivänä olevista lehmistä. Keskipoikimakerta kuvaa lähinnä karjassa olevien lehmien potentiaalista elinikäistä kannattavuutta, elinikäistuotoksen ja poikimakerran hyvän korrelaation vuoksi. Tarkempi menetelmä olisi laskea poikimakerrat ruokintapäivien määrällä painotettuna, mutta kumpikaan laskutapa ei tosin näytä selkeästi, jos karjasta poistetaan paljon ensikoita muutaman kuukauden sisällä poikimisesta. Siksi sekä uudistusprosentin että keskipoikimakerran yhtäaikainen tarkastelu on hyödyllistä. Karjan poikimakertojen ilmoittaminen frekvenssijakaumana, ns. herd composition, soveltuisi paremmin poikimakerran luokkamuuttujaluonteelle (Radke ja Shook 2001).

\section{Johtopäätökset}

Lypsylehmien kestävyyttä voidaan kuvata sekä lehmä- että karjakohtaisilla muuttujilla, jotka täydentävät toisiaan, joten useamman kuin yhden tunnusluvun tarkastelu on suositeltavaa. Karjassa olevien lehmien kestävyyden lisäksi etenkin poistettujen lehmien tunnuslukujen tarkastelu usean vuoden ajalta on luotettava, karjakoon muutoksista ja sattumasta vähemmän häiriytyvä tapa selvittää missä karjan kestävyyden kanssa mennään.

\section{Kirjallisuus}

Dredge, K. 2003. Lypsylehmien tuotantokestävyys ja poistopolitiikka osana karjan terveydenhuoltoa. Suomen Eläinlääkärilehti 109:196-202.

Dürr, J.W., Monardes, H.G, Cue, R.I. \& Philpot, J.C. 1997. Culling in Quebec holstein herds. 1. Study of Phenotypic Trends in Herd Life. Can. J. Anim. Sci. 77:593-600.

Radke, B. \& Shook, G. 2001. Cullig and genetic inprovement programs for dairy herds. In: Radostis, O.M. (Ed.) Herd health. Food animal production medicine. Third edition. Philadelphia. pp. 291-308.

Rajala-Schultz, P.J., Gröhn, Y.T. \& Allore, H.G. 2000. Optimizing replacenment decisions for Finnish dairy herds. Acta. Vet. Scand. 41: 185-198.

Voutilainen, P., Tuhkanen, H.-R., Katajajuuri, J.-M. \& Nousiainen, J.I. 2003. Emmental Sinileima -juuston tuotantoketjun ympäristövaikutukset ja parannusmahdollisuudet. Maa- ja elintarviketalous 35: 91 s. +2 liitettä. 